\title{
Dose-response comparison of ipratropium bromide from a metered-dose inhaler and by jet nebulisation
}

\author{
SA GOMM, NP KEANEY, LP HUNT, SC ALLEN, TB STRETTON \\ From the Department of Respiratory Medicine, Manchester Royal Infirmary, Manchester
}

ABSTRACT The dose-response relationships of the anticholinergic bronchodilator drug ipratropium bromide were studied. Cumulative doses totalling $288 \mu \mathrm{g}$ ipratropium were given by inhalation of a liquid aerosol from a Wright nebuliser to each of 10 patients with stable, moderately severe airflow obstruction. Up to $80 \%$ of the maximum achievable bronchodilator response, as assessed by a rise in the patients' mean forced expiratory volume in one second $\left(\mathrm{FEV}_{1}\right)$, was obtained with a cumulative total dose of $72 \mu \mathrm{g}$; with additional doses beyond $72 \mu \mathrm{g}$ there was no significant further improvement. In the same patients the effects of administration of cumulative doses of ipratropium to a total of $72 \mu \mathrm{g}$ from a Wright nebuliser were compared with those achieved with a metered-dose inhaler. Bronchodilatation was assessed by measurement of peak expiratory flow rate, $\mathrm{FEV}_{1}$, forced vital capacity, thoracic gas volume and specific airways conductance (sGaw). No significant difference was observed in the response at any dose level between the wet and the dry aerosols. By fitting a curve to the mean values of FEV and $_{\text {sGaw }}$ an estimate was made of the dose of ipratropium bromide required to produce $99 \%$ of the achievable bronchodilator response. For $\mathrm{FEV}_{1}$ this dose was $78 \mu \mathrm{g}$ when ipratropium was inhaled as a nebulised solution from the Wright nebuliser and $82 \mu \mathrm{g}$ when it was inhaled from the metered-dose inhaler; for sGaw the respective values were 54 and $58 \mu \mathrm{g}$. In these patients with stable airflow obstruction there was no therapeutic advantage in the use of ipratropium bromide as a wet aerosol.

The inhalation of low doses of a bronchodilator drug from a pressurised metered-dose inhaler is standard practice in the maintenance treatment of reversible airflow obstruction. For acute exacerbations necessitating admission to hospital large doses of the bronchodilator are often administered by nebulisation of a solution of the drug, with or without the assistance of intermittent positive-pressure ventilation. Previous reports ${ }^{1-3}$ of the superiority of liquid nebulisation over a metered-dose inhaler for administering $\beta$-adrenoceptor bronchodilator aerosols appear to overlook the discrepancy between the doses administered. We have made a comparative study of the bronchodilator effect of the anticholinergic drug ipratropium bromide given in equal, low doses by jet nebulisation and from a metered-dose inhaler. Ipratropium bromide is being

Address for reprint requests: Dr SA Gomm, Department of Chest Medicine, Wythenshawe Hospital, Manchester M23 9LT.

Accepted 1 December 1982 used increasingly in the treatment of patients with airflow obstruction, a dose of 20-80 $\mu \mathrm{g}$ from a metered-dose inhaler producing a peak effect after 30-40 minutes and an action which may persist for up to six hours. ${ }^{4-6}$ The objectives of the present study were twofold: firstly, to determine the dose of ipratropium given as a nebulised solution which was needed to produce a plateau in the magnitude of the resulting bronchodilatation and, secondly, to compare the dose-response relationships of administering equal doses of the drug from a Wright nebuliser and a metered-dose inhaler.

\section{Methods}

The study was performed on 10 patients aged $20-67$ years, whose clinical details are summarised in table 1. Eight of the subjects had bronchial asthma and two chronic bronchitis; nine were non-smokers. Individuals were excluded if they had evidence of any other bronchopulmonary disease or disease in any other system. Each patient gave informed con- 
Table 1 Details of the patients in the study, with baseline forced expiratory volume in one second (FEV $)$ and improvement $\ddot{\vec{B}}$ 15 minutes after inhalation of $200 \mu \mathrm{g}$ salbutamol

\begin{tabular}{|c|c|c|c|c|c|c|c|}
\hline \multirow[t]{3}{*}{ Patient } & \multirow[t]{3}{*}{ Sex } & \multirow{3}{*}{$\begin{array}{l}\text { Age } \\
(y)\end{array}$} & \multirow{3}{*}{$\begin{array}{l}\text { Duration } \\
\text { of illness } \\
(y)\end{array}$} & \multirow[t]{3}{*}{ Diagnosis* } & \multicolumn{3}{|l|}{$F E V_{1}$} \\
\hline & & & & & \multicolumn{2}{|c|}{ Baseline } & \multirow{2}{*}{$\begin{array}{l}\text { Improvemen } \\
\text { after } \\
\text { salbutamol } \\
\text { (l) }\end{array}$} \\
\hline & & & & & $l$ & $\begin{array}{l}\% \\
\text { predicted }^{9}\end{array}$ & \\
\hline 1 & $\mathbf{M}$ & 20 & 10 & A & 2.68 & 63 & 3.23 \\
\hline 2 & M & 52 & 30 & CB & 0.96 & 29 & 1.19 \\
\hline 3 & $F$ & 39 & 36 & A & $1 \cdot 17$ & 46 & 1.80 \\
\hline 4 & $\mathbf{M}$ & 47 & 34 & A & 1.38 & 40 & 1.66 \\
\hline 5 & $\mathrm{~F}$ & 60 & 14 & A & 0.94 & 43 & 1.27 \\
\hline 6 & $\mathrm{M}$ & 63 & 10 & CB & $1 \cdot 23$ & 43 & 1.48 \\
\hline 7 & M & 34 & 6 & A & 1.86 & 41 & 2.29 \\
\hline 8 & $\mathrm{~F}$ & 58 & 5 & A & 1.52 & 65 & $2 \cdot 28$ \\
\hline 9 & $\mathrm{~F}$ & 62 & 10 & A & 1.08 & 60 & $1 \cdot 36$ \\
\hline 10 & $\mathbf{M}$ & 67 & 9 & A & 1.98 & 56 & $2 \cdot 45$ \\
\hline
\end{tabular}

sent to the study. All had a baseline forced expiratory volume in one second $\left(\mathrm{FEV}_{1}\right)$ which was less than $70 \%$ of their predicted normal value 9 and an improvement in $\mathrm{FEV}_{1}$ of more than $20 \%$ after inhaling $200 \mu \mathrm{g}$ of salbutamol. In addition, their $\mathrm{FEV}_{1}$ did not vary by more than $121 / 2 \%$ between study days. Bronchodilator drugs were discontinued for the 12 hours preceding each experiment but patients receiving corticosteroids or disodium cromoglycate continued these drugs during the study. All the patients were experienced users of metered-dose inhalers.

Ipratropium bromide was supplied in two ways: (a) from a pressurised metered-dose inhaler, each activation delivering $18 \mu \mathrm{g}$ to the patient, and $(b)$ as a solution administered from a Wright nebuliser ${ }^{10}$ in a dilution such that the required dose of ipratropium could be delivered during two minutes of nebulisation via an MC face mask at an oxygen flow rate of 6 litres a minute. Each patient was instructed to use tidal breathing when the solution of ipratropium was inhaled from the Wright nebuliser. In a series of 10 two-minute nebulisations it was shown by weighing the Wright nebuliser beforehand and afterwards that the mean volume of solution emitted was $440 \mu \mathrm{l}$ $\pm 47 \mu \mathrm{l}$ (SEM). A stock solution of ipratropium was prepared containing $144 \mu \mathrm{g} / \mathrm{ml}$ and aliquots of this were diluted in normal saline to deliver the desired dose on the assumption that $440 \mu$ l of diluted solution would be emitted. The same Wright nebuliser containing $5.0 \mathrm{ml}$ of diluted solution was used throughout the study.

\section{CUMULATIVE INHALATION STUDY USING JET}

NEBULISATION

The patients attended the laboratory at 9 am and rested for 20 minutes. Baseline values of PEFR, $\mathrm{FEV}_{1}$ and FVC were measured on an Ohio 842 dry cylinder spirometer and the pulse rate was recorded.
Ipratropium bromide was administered from the $\vec{\nabla}$ Wright nebuliser through a face mask in doses of 18 , 을. $18,36,72$ and $144 \mu \mathrm{g}$ at 30 -minute intervals. The physiological measurements were repeated before $\ddot{\oplus}$ each succeeding dose of ipratropium and 30 minutes after the last dose.

\section{DOSE-RESPONSE COMPARISON USING \\ METERED-DOSE INHALER AND JET \\ NEBULISATION}

The patients attended the laboratory on two consecutive days. They rested for 20 minutes and con- $\frac{0}{3}$ trol values of peak expiratory flow rate, $\mathrm{FEV}_{1}$, forced vital capacity (FVC), thoracic gas volumeo (TGV), airways resistance (Raw), and pulse rate were recorded. Measurements of PEFR, FEV ${ }_{1}$, ando FVC were made with an Ohio 842 spirometer. $A \underset{\times}{\tilde{0}}$ pressure-corrected flow plethysmograph (Fenyveso and Gut) was used to measure TGV and Raw" and $\underline{3}$. the results were expressed as the reciprocal of air-ô ways resistance per litre of thoracic gas volumethat is, specific airways conductance (sGaw). 을

On one treatment day each subject received ipra- $\rightarrow$ tropium bromide from a metered-dose inhaler at을 30 -minute intervals in doses of 18,18 , and $36 \mu \mathrm{g}$. N On the other treatment day ipratropium was inhaled ${ }^{\circ}$ through a face mask from the Wright nebuliser in 0 doses of $9,9,18$, and $36 \mu \mathrm{g}$ at 30-minute intervals. N The method of administration on the first treatmento day was randomly allocated to each patient. Theo physiological measurements were repeated $30 \widetilde{\odot}$ minutes after each dose of ipratropium and at $30 \stackrel{\mathcal{N}}{?}$ and 60 minutes after the patient had received at cumulative dose of $72 \mu \mathrm{g}$. This was done for each울 method of administration of the drug. Dose- $\AA$ response curves were prepared and the results for $\vec{Q}$ the two methods of administration were compared.o The significance of differences between the mean values were compared by paired $t$ tests and $a$ 


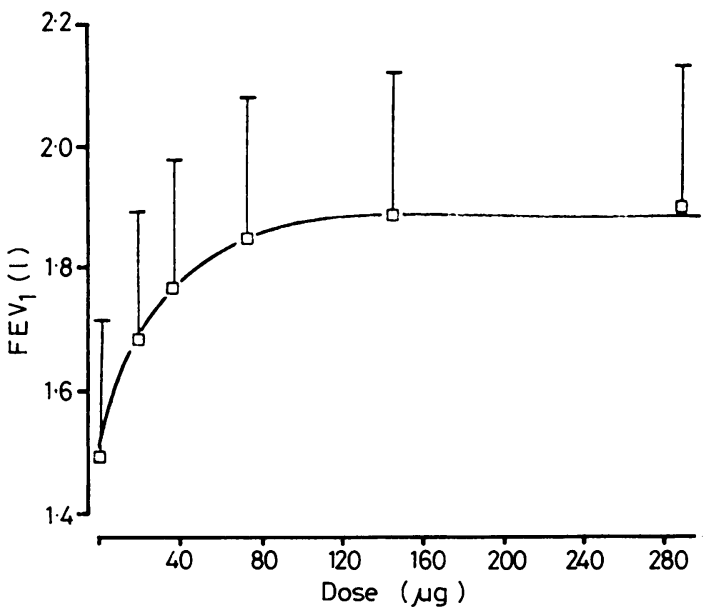

Fig 1 Mean values ( $\pm S E M)$ of $F E V_{1}$ (l) after administration of ipratropium bromide from a Wright nebuliser to a cumulative dose of $288 \mu \mathrm{g}$ in 10 patients, each value of FEV after the first representing the value observed 30 minutes after inhalation of the indicated dose.

multivariate equivalent using one-sample Hotelling's $T^{2}{ }^{12}$

\section{Results}

\section{CUMULATIVE INHALATION STUDY USING JET} NEBULISATION

The mean control value for $\mathrm{FEV}_{1}$ before the patients used the Wright nebuliser was $1 \cdot 50 \pm 0.22$ litres. The maximum value obtained for $\mathrm{FEV}_{1}$ was $1.92 \pm 0.28 \mathrm{l}$; this occurred 30 minutes after the cumulative inhalation of $288 \mu \mathrm{g}$ of ipratropium. The bronchodilatation at each dose level was highly significant $(p<0.001$ ) (fig 1). The cumulative administration of $72 \mu \mathrm{g}$ of ipratropium by jet nebulisation produced $80 \%$ of the maximum improvement in $\mathrm{FEV}_{1}$ and there was no significant difference between the $72 \mu \mathrm{g}$ and $288 \mu \mathrm{g}$ dose levels.

\section{DOSE-RESPONSE COMPARISON USING METERED-DOSE INHALER AND JET NEBULISATION}

The mean baseline FEV, before the patients used the metered-dose inhaler was $1.49 \pm 0.191$ and before jet nebulisation $1 \cdot 52 \pm 0 \cdot 21 \mathrm{l}$. There was no significant difference in the mean maximum postbronchodilator values of $\mathrm{FEV}_{1}$, which were $2.09 \pm$ 0.281 and $1.97 \pm 0.271$ respectively. The cumulative administration of $72 \mu \mathrm{g}$ of ipratropium bromide by both methods produced highly significant improvements $(p<0.001)$ in the mean values for PEFR, FEV, FVC, TGV, and sGaw at the cumulated $18 \mu \mathrm{g}, 36 \mu \mathrm{g}$, and $72 \mu \mathrm{g}$ dose levels and at 30 and 60 minutes after inhalation of $72 \mu \mathrm{g}$ of ipratropium (table 2). The changes which occurred with each dose increment above the cumulated $18 \mu \mathrm{g}$ level were not, however, significant. For all measured respiratory indices at each dose level there was no significant difference between the response to

Table 2 Comparison in 10 patients with airflow obstruction of metered-dose inhaler $(A)$ and Wright nebuliser (B): results of spirometry and whole-body plethysmography (means $\pm S E M)^{*}$

\begin{tabular}{|c|c|c|c|c|c|c|c|c|}
\hline & & \multirow{2}{*}{$\begin{array}{l}\text { Base- } \\
\text { line }\end{array}$} & \multicolumn{4}{|c|}{ Cumulative dose ipratropium } & \multicolumn{2}{|c|}{$\begin{array}{l}\text { Minutes after } 72 \mu \mathrm{g} \\
\text { dose level }\end{array}$} \\
\hline & & & $9 \mu g$ & $18 \mu g$ & $36 \mu g$ & $72 \mu g$ & 30 & 60 \\
\hline \multirow[t]{2}{*}{$\mathrm{FEV}_{1}(\mathrm{l})$} & A & 1.49 & & $1 \cdot 88$ & $2 \cdot 00$ & $2 \cdot 06$ & $2 \cdot 00$ & $2 \cdot 02$ \\
\hline & B & $\begin{array}{l}(0.19) \\
1 \cdot 52 \\
(0 \cdot 21)\end{array}$ & $\begin{array}{l}1 \cdot 71 \\
(0 \cdot 22)\end{array}$ & $\begin{array}{l}(0.23) \\
1.86 \\
(0 \cdot 25)\end{array}$ & $\begin{array}{l}(0.27) \\
1.90 \\
(0 \cdot 25)\end{array}$ & $\begin{array}{l}(0.29) \\
1.96 \\
(0 \cdot 26)\end{array}$ & $\begin{array}{l}(0 \cdot 27) \\
1 \cdot 89 \\
(0 \cdot 23)\end{array}$ & $\begin{array}{l}(0.27) \\
1.74 \\
(0.23)\end{array}$ \\
\hline \multirow[t]{2}{*}{ FVC (l) } & A & $\begin{array}{c}2.63 \\
(0.31)\end{array}$ & & $\begin{array}{l}3 \cdot 10 \\
(0 \cdot 34)\end{array}$ & $\begin{array}{l}3.25 \\
(0.33)\end{array}$ & $\begin{array}{c}3.28 \\
(0.35)\end{array}$ & $\begin{array}{c}3.42 \\
(0.33)\end{array}$ & $\begin{array}{r}3.36 \\
(0.30)\end{array}$ \\
\hline & B & $\begin{array}{l}2 \cdot 66 \\
(0 \cdot 32)\end{array}$ & $\begin{array}{c}2 \cdot 87 \\
(0 \cdot 34)\end{array}$ & $\begin{array}{l}3 \cdot 10 \\
(0.35)\end{array}$ & $\begin{array}{c}3.22 \\
(0.36)\end{array}$ & $\begin{array}{c}3.11 \\
(0 \cdot 37)\end{array}$ & $\begin{array}{l}3 \cdot 15 \\
(0 \cdot 30)\end{array}$ & $\begin{array}{r}3.03 \\
(0.30)\end{array}$ \\
\hline \multirow[t]{2}{*}{$\operatorname{PEFR}\left(1 \min ^{-1}\right)$} & A & $\begin{array}{l}209 \\
(29)\end{array}$ & & $\begin{array}{l}259 \\
(37)\end{array}$ & $\begin{array}{l}285 \\
(43)\end{array}$ & $\begin{array}{l}293 \\
(44)\end{array}$ & $\begin{array}{l}272 \\
(40)\end{array}$ & $\begin{array}{l}275 \\
(39)\end{array}$ \\
\hline & B & $\begin{array}{l}208 \\
(29)\end{array}$ & $\begin{array}{l}236 \\
(29)\end{array}$ & $\begin{array}{l}266 \\
(32)\end{array}$ & $\begin{array}{l}273 \\
(36)\end{array}$ & $\begin{array}{l}266 \\
(40)\end{array}$ & $\begin{array}{l}259 \\
(32)\end{array}$ & $\begin{array}{l}234 \\
(34)\end{array}$ \\
\hline \multirow[t]{2}{*}{$\begin{array}{l}\text { sGaw } \\
\left(\mathrm{s}^{-1} \mathrm{kPa}^{-1}\right)\end{array}$} & A & $\begin{array}{c}0.46 \\
(0 \cdot 06)\end{array}$ & & $\begin{array}{c}0.99 \\
(0 \cdot 16)\end{array}$ & $\begin{array}{c}0.98 \\
(0 \cdot 18)\end{array}$ & $\begin{array}{c}1 \cdot 16 \\
(0 \cdot 23)\end{array}$ & $\begin{array}{c}1 \cdot 15 \\
(0 \cdot 24)\end{array}$ & $\begin{array}{c}1 \cdot 17 \\
(0.33)\end{array}$ \\
\hline & B & $\begin{array}{c}0.52 \\
(0.08)\end{array}$ & $\begin{array}{c}0 \cdot 68 \\
(0 \cdot 16)\end{array}$ & $\begin{array}{c}0.88 \\
(0.16)\end{array}$ & $\begin{array}{r}0.89 \\
(0.14)\end{array}$ & $\begin{array}{c}0.90 \\
0.13)\end{array}$ & $\begin{array}{c}(0.24) \\
0.94\end{array}$ & $\begin{array}{c}(0.35) \\
0.86\end{array}$ \\
\hline \multirow[t]{2}{*}{ TGV (1) } & A & $\begin{array}{c}4.43 \\
(0.33)\end{array}$ & & $\begin{array}{l}(0.10) \\
4.15 \\
(0.34)\end{array}$ & $\begin{array}{c}(0 \cdot 14) \\
4 \cdot 14 \\
(0.36)\end{array}$ & $\begin{array}{c}(0.13) \\
4 \cdot 02 \\
(0.31)\end{array}$ & $\begin{array}{c}(0.23) \\
3.93 \\
(0.28)\end{array}$ & $\begin{array}{l}(0.19) \\
3.87\end{array}$ \\
\hline & B & $\begin{array}{c}4.45 \\
(0.38)\end{array}$ & $\begin{array}{c}4 \cdot 26 \\
(0 \cdot 37)\end{array}$ & $\begin{array}{c}(\cdot .06) \\
4 \cdot 06 \\
(0 \cdot 36)\end{array}$ & $\begin{array}{c}(0 \cdot 30) \\
4 \cdot 02 \\
(0 \cdot 33)\end{array}$ & $\begin{array}{c}(0 \cdot 31) \\
3 \cdot 96 \\
(0 \cdot 31)\end{array}$ & $\begin{array}{c}(0 \cdot 28) \\
3 \cdot 94 \\
(0 \cdot 29)\end{array}$ & $\begin{array}{c}(0 \cdot 30) \\
4 \cdot 03 \\
(0.32)\end{array}$ \\
\hline
\end{tabular}

FVC - forced vital capacity; PERF-peak expiratory flow rate; sGaw-specific conductance; TGV-thoracic gas volume.

*The mean improvement in FEV, FVC, PEFR, TGV, and sGaw compared to baseline values was significant (p< $0 \cdot 001)$ at the cumulated 18,36 , and $72 \mu \mathrm{g}$ dose levels and at 30 and 60 minutes. Improvement in FVC, TGV, and sGaw was not significant at the $9 \mu \mathrm{g}$ dose (n $=$ $10)$. 


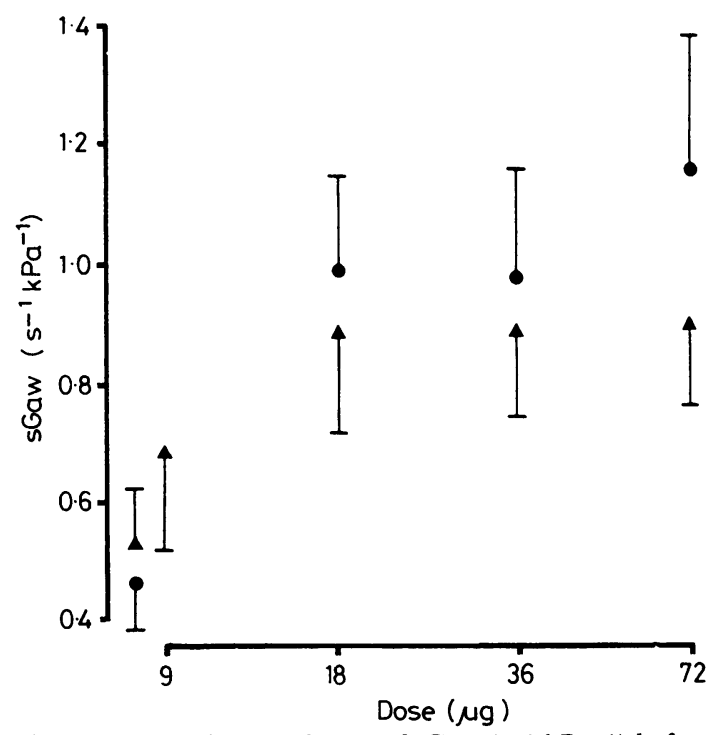

Fig 2 Mean values ( \pm SEM) of $s$ Gaw $\left(s^{-1} k \mathrm{~Pa}^{-1}\right)$ before and after administration of ipratropium bromide to a cumulative dose of $72 \mu \mathrm{g}$ from a metered-dose inhaler (O) and $a$ Wright nebuliser $(\Delta)$ in 10 patients.

ipratropium bromide with the metered-dose inhaler and that achieved with the Wright nebuliser (table 2 and fig 2).

For each method of administration the bronchodilator effect of ipratropium as measured by the mean values of $\mathrm{FEV}_{1}$ and sGaw appeared to be exponentially related to the dose of drug received and it fitted a curve of the form $y=\mathrm{A}-\mathrm{Be}^{-\mathrm{Cx}}$ (fig 3 ). In the equation $y$ is the mean value of $\mathrm{FEV}_{1}$ or sGaw; $x$ is the cumulative dose $(\mu \mathrm{g})$ of ipratropium bromide; $\mathrm{A}$ is the theoretical maximum bronchodilator response; $\mathrm{B}$ is the maximum increase in the mean values of $F E V_{1}$ or sGaw; $A-B$ is the response before ipratropium bromide was inhaled and $C$ is a constant of proportionality. The constants $\mathrm{A}, \mathrm{B}$, and $\mathrm{C}$ were estimated by a method of iterative computer analysis. ${ }^{13}$ The curve obtained for each response was plotted graphically and the actual data points for $\mathrm{FEV}_{1}$ and sGaw were inserted for comparison. The dose of ipratropium bromide required to produce $99 \%$ of the theoretical maximum bronchodilator response was estimated from the doseresponse curves. For FEV, this dose was $78 \mu \mathrm{g}$ when the drug was inhaled as a nebulised solution from the Wright nebuliser and $82 \mu \mathrm{g}$ when it was inhaled from the metered-dose inhaler; for sGaw the respective values were 54 and $58 \mu \mathrm{g}$.

The mean baseline value for pulse rate when the patients used the metered-dose inhaler was 82 beats per minute ( \pm SD 8.2 ) and 81 beats/min $( \pm 10)$ when they used the nebuliser. The maximum values

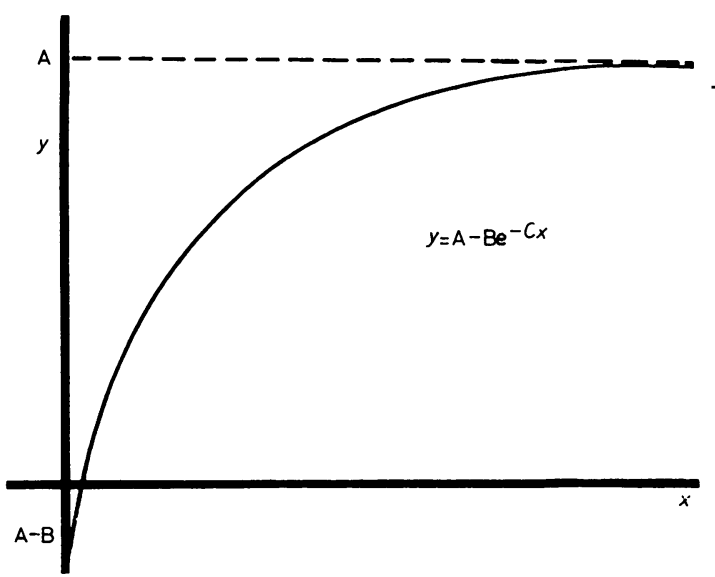

Fig 3 The exponential model $y=A-B e^{-C x}$, to which the dose-response data were fitted. $y=$ mean $F E V$, or sGaw (l); $x=$ cumulative dose ( $\mu \mathrm{g})$ of ipratropium; $A$ is the theoretical maximum bronchodilator response; $B$ is the maximum increase in the mean values; $A-B$ is the response before the drug was inhaled; and $C$ is a constant of proportionality.

recorded were $86( \pm 9 \cdot 1)$ and $84( \pm 11 \cdot 1)$ beats $/ \mathrm{min}$ respectively.

\section{Discussion}

The results of the initial study in this group of patients with moderately severe airflow obstruction showed that about $80 \%$ of the maximum bronchodilatation produced by ipratropium bromide could be achieved with a cumulative dose of $72 \mu \mathrm{g}$. When the effects of equivalent doses of the drug given by metered-dose inhaler and as a nebulised solution were then compared there was no evident 3 . difference in the degree of bronchodilatation achieved.

Important factors influencing aerosol penetration 0 into the lungs include the size and distribution of the particles inhaled,,$^{14}$ the technique of inhalation, ${ }^{15-17}$ and abnormalities in the airway structure. ${ }^{18}$ The diameter of particles delivered by a metered-dose o inhaler is reported to be below $5 \mu \mathrm{m}^{19}$ and from aN Wright nebuliser below $8 \mu \mathrm{m} .{ }^{10}$ In the present study the techniques of inhalation of the bronchodilator under investigation were intentionally different but the degree of airflow obstruction in the participants was of comparable severity on the days when ipra- $\stackrel{\infty}{+}$ tropium was administered by the two methods.

Shenfield and coworkers ${ }^{20}$ reported that less thano $20 \%$ of the delivered dose of nebulised salbutamol迎 enters the patient, the proportion reaching the lungsi being uncertain; while $10 \%$ of the delivered dose from a metered-dose inhaler is estimated to enter the lungs. ${ }^{22}$ Our findings of comparable bron- 


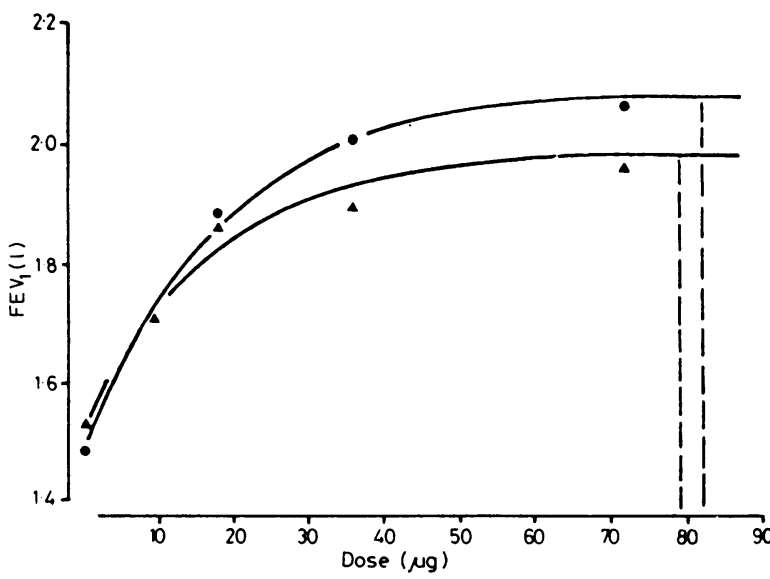

Fig 4 The exponential model $y=A-B e^{-\mathrm{C} x}$ fitted to the mean values of $F E V$, when ipratropium bromide was administered from a metered-dose inhaler (O) and a Wright nebuliser ( $\mathbf{\Delta})$ to a cumulative dose of $72 \mu \mathrm{g}$. - - - indicates estimated dose of ipratropium needed to achieve $99 \%$ of the bronchodilator effect.

chodilatation and dose-response curves with the two modes of administration of ipratropium bromide suggest that equivalent amounts of the drug reached the site of action in the airways on these two occasions. A cumulated dose of $72 \mu \mathrm{g}$ of ipratropium bromide was estimated from the dose-response curve for $\mathrm{FEV}_{1}$ (fig 4) to produce about $95 \%$ of the maximum bronchodilator response and the principal advantage of a higher dose would be a longer duration of action. ${ }^{6}$

In conclusion, it appears that for patients with a moderate degree of airflow obstruction (mean baseline $\mathrm{FEV}_{1}<45 \%$ of predicted) who are experienced users of metered-dose inhalers there is no therapeutic advantage in the use of ipratropium bromide by jet nebulisation. Nevertheless, the administration of the drug by this technique may be of advantage during a severe exacerbation of airflow obstruction, when a patient may be unable to use a metered-dose inhaler efficiently.

\section{References}

${ }^{1}$ Evans ME, Paterson JW, Richards AJ, Walker SR. Pharmacokinetics of inhaled salbutamol in asthmatic patients. Br J Pharmacol 1971;43:466-76P.

${ }^{2}$ Chang $\mathrm{N}$, Levison $\mathrm{H}$. The effect of a nebulised bronchodilator administered with and without IPBB on ventilatory function in children with cystic fibrosis and asthma. Am Rev Respir Dis 1972;106:867-72.

${ }^{3}$ Choo-Kang YFJ, Grant IWB. Comparison of two methods of administering bronchodilator aerosols to asthmatic patients. $\mathrm{Br}$ Med J 1975;ii:119-20.

${ }^{4}$ Loddenkemper R. Dose- and time-response of Sch 1000 MDI on total $\left(R_{t}\right)$ and expiratory $\left(R_{e}\right)$ airways resistance in patients with chronic bronchitis and emphysema. Postgrad Med J 1975;51, suppl 7:97.

${ }^{5}$ Meier J, Wagner E. Dose- and time-response relationship of Sch 1000 MDI in a controlled comparison with placebo, as assessed by total airways resistance $\left(R_{e}\right)$, thoracic gas volume (TGV) and some other ventilatory and circulatory parameters. Postgrad Med J 1975;51, suppl 7:98.

' Allen JA, Campbell AH. Dose response of ipratropium bromide assessed by two methods. Thorax 1980; 34:137-9.

${ }^{7}$ Ciba Foundation Study Group No 38. Identification of asthma. Edinburgh: Churchill Livingstone, 1971:13$34,172-4$.

${ }^{8}$ Medical Research Council. Definitions and classification of chronic bronchitis. Lancet 1965;i:775-9.

${ }^{9}$ Cotes JE. Lung function: assessment and application in medicine. 4th ed. Oxford: Blackwell Scientific Publications 1979:377-8.

${ }^{10}$ Wright BM. A new nebuliser. Lancet 1958;ii:24.

"Stanescu DC, DeSutter P, Van de Worstigne KP. Pressure corrected flow body plethysmograph. Am Rev Respir Dis 1972;105:304-5.

${ }_{12}$ Morrison DF. Multivariate statistical methods. 2nd ed. Tokyo: McGraw Hill, 1976;128-34, 141-52.

${ }^{13}$ Nelder JA, Mead R. A simple method for function minimisation. Computer J 1965;7:308-13.

${ }^{14}$ Godfrey S, Zeidford E, Brown K, Brown JH. The possible site of action of sodium cromoglycate assessed by exercise challenge. Clin Sci Mol Med 1974;46:26572.

${ }^{15}$ Booker DV, Chamberlain AC, Rundo J, Muir DCF, Thomson ML. Elimination of $5 \mu$ particles from the human being. Nature 1967;215:30-3.

${ }^{16}$ Goldberg IS, Lourenço RV. Deposition of aerosols in pulmonary disease. Arch Intern Med 1973;131:88-91.

${ }^{17}$ Pavia D, Thomson ML, Clarke SW, Shannon HS. Effect of lung function and mode of inhalation on penetration of aerosol into the human lung. Thorax 1977:32:194-7.

${ }^{18}$ Thomson ML, Short MD. Mucociliary function in health, chronic obstructive airway disease and asbestosis. J Appl Physiol 1969;26:535-9.

${ }^{19}$ Muir DCF. Physical properties of therapeutic aerosols: In Clinical aspects of inhaled particles. London: Heinemann, 1972;182.

${ }^{20}$ Shenfield GM, Evans MR, Paterson JW. The effect of different nebulisers with and without intermittent positive pressure breathing on the absorption and metabolism of salbutamol. Br J Clin Pharmacol 1974;1:295-300.

${ }^{21}$ Davies DS. Pharmacokinetics of inhaled substances. Postgrad Med J 1975;51, suppl 7, 69-73.

${ }^{22}$ Newman SP, Pavia D, Sheahan NF, Moren F, Clarke SW. Deposition of pressurised aerosols in the lung using radiolabelled particles. Thorax 1980;35:234P. 
depolarising muscle relaxants were avoided and paralysis was induced with pancuronium. There were no difficulties with ventilation in this period and, although moderate hypothermia is known to potentiate all types of neuromuscular blockade ${ }^{3}$ the patient showed no abnormal requirements or sensitivity to the dose administered and was responding to commands at the end of the procedure. To avoid inducing myotonia we did not use halothane, which commonly produces postoperative shivering.

Another potential difficulty in paramyotonia congenita relates to the electrolyte shifts which may occur with haemodilution and cardiopulmonary bypass. In particular, hyperkalaemia may precipitate myotonia. ${ }^{1}$ The primary muscle defect is thought to be related to increased sodium conductance in affected muscles. An infusion of $80 \mathrm{mmol}$ (mEq) of potassium chloride in $500 \mathrm{ml} 5 \%$ dextrose infused at $80 \mathrm{ml} / \mathrm{h}$ was able to prevent gross fluctuations in serum potassium concentrations in this patient.

Only minimal postoperative respiratory depression was seen, with a transient rise in arterial $\mathrm{PCO}_{2}$. The major postoperative difficulty encountered was the occurrence of brief episodes of hypotension and falling central venous pressures, which were not significantly affected by volume loading or by dopamine infusion. Although the aetiology of these haemodynamic changes is not definitely known, they were possibly related to sudden changes in peripheral resistance or venous capacitance or both. The attacks proved benign, though they did increase the duration of the patient's stay in the intensive care unit.

In summary, cardiopulmonary bypass using moderate hypothermia has been undertaken safely in a patient with paramyotonia congenita. Depolarising muscle relaxants and halothane were avoided, and complete rewarming on bypass was carefully carried out. The anticipated respiratory difficulties did not occur and postoperative recovery was complete.

\section{References}

' Thrush DC, Morris CT, Salmon MV. Paramyotonia congenita: a clinical, histochemical and pathological study. Brain 1972;95:537-45.

${ }^{2}$ Utley JR, Wachtel C, Cain RB, Spaw EA, Collins JC, Stephens DB. Effects of hypothermia, hemodilution, and pump oxygenation on organ water content, blood flow and oxygen delivery, and renal function. Ann Thorac Surg 1981;31:121-33.

${ }^{3}$ Thornton RJ, Blakeney C, Feldman SA. Summary presented to the Anaesthetic Research Group. The effect of hypothermia on neuromuscular conduction. Br J Anaesth 1976;48:264.

\section{Correction} Dose-response comparison of ipratropium bromide from a
metered-dose inhaler and by jet nebulisation

In the paper by SA Gomm and others (April, pp 297-301) we regret an error in line 3 of the last paragraph, where "<45\%" should be "> $45 \%$." 